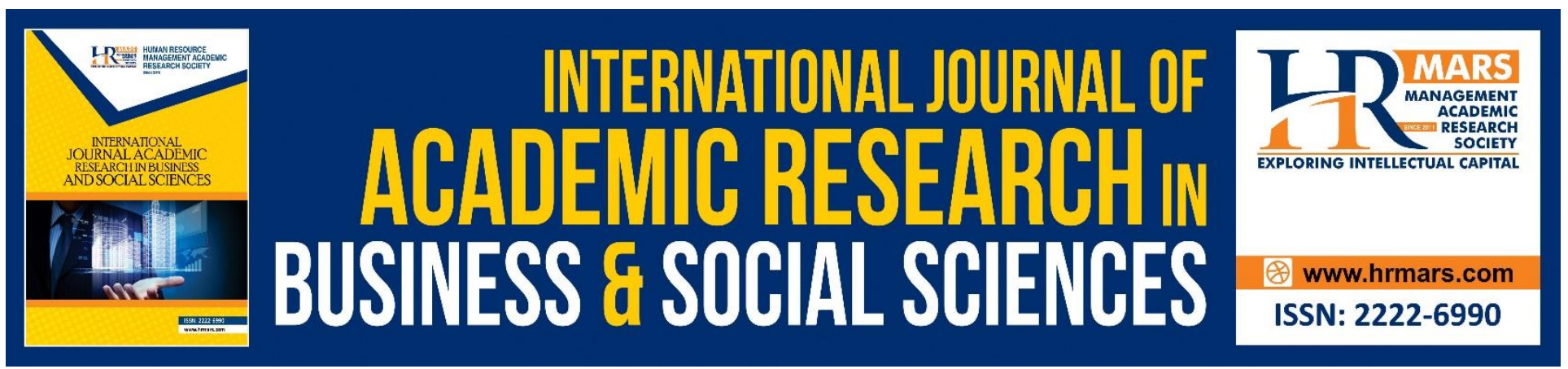

\title{
Determinants of Financial Distress among the Companies Practise Note 17 Listed in Bursa Malaysia
}

\author{
Mohamad Nizam Jaafar, Amirul Afif Muhamat, \\ Sharifah Faigah Syed Alwi, Norzitah Abdul Karim, \\ Syafini binti A. Rahman
}

To Link this Article: http://dx.doi.org/10.6007/IJARBSS/v8-i11/956

DOI: $\quad 10.6007 /$ IJARBSS/v8-i11/4956

Received: 19 Oct 2018, Revised: 29 Nov 2018, Accepted: 06 Nov 2018

Published Online: 12 Nov 2018

In-Text Citation: (Jaafar, Muhamat, Alwi, Karim, \& Rahman, 2018)

To Cite this Article: Jaafar, M. N., Muhamat, A. A., Alwi, S. F. S., Karim, N. A., \& Rahman, S. binti A. (2018). Determinants of Financial Distress among the Companies Practise Note 17 Listed in Bursa Malaysia. International Journal of Academic Research in Business and Social Sciences, 8(11), 798-809.

Copyright: (C) 2018 The Author(s)

Published by Human Resource Management Academic Research Society (www.hrmars.com)

This article is published under the Creative Commons Attribution (CC BY 4.0) license. Anyone may reproduce, distribute, translate and create derivative works of this article (for both commercial and non-commercial purposes), subject to full attribution to the original publication and authors. The full terms of this license may be seen

at: http://creativecommons.org/licences/by/4.0/legalcode

Vol. 8, No. 11, 2018, Pg. 800 - 811

http://hrmars.com/index.php/pages/detail/IJARBSS

JOURNAL HOMEPAGE

Full Terms \& Conditions of access and use can be found at http://hrmars.com/index.php/pages/detail/publication-ethics 


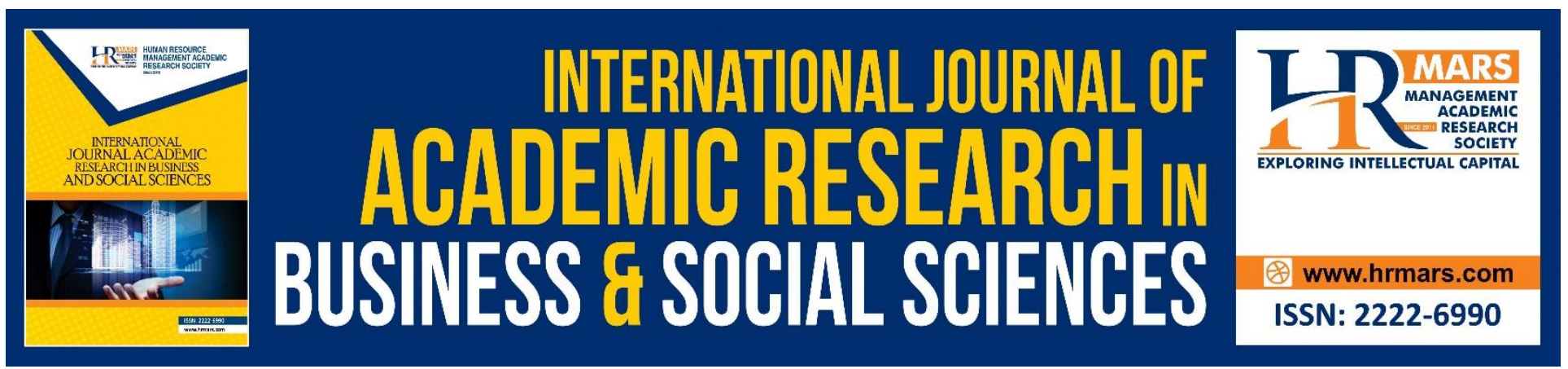

\title{
Determinants of Financial Distress among the Companies Practise Note 17 Listed in Bursa Malaysia
}

\author{
Mohamad Nizam Jaafar ${ }^{1}$, Amirul Afif Muhamat ${ }^{2}$, \\ Sharifah Faigah Syed Alwi ${ }^{1}$, Norzitah Abdul Karim ${ }^{2}$, \\ Syafini binti A.Rahman ${ }^{1}$ \\ ${ }^{1}$ Arshad Ayub Graduate Business School, Universiti Teknologi MARA, 40450 Shah Alam \\ Malaysia \\ ${ }^{2}$ Faculty of Business Management, Universiti Teknologi MARA, Selangor, Malaysia.
}

\begin{abstract}
The failure of companies to remain profit incurred gradually over several years. Market value of a company under financial distress will reduce; as suppliers prefer cash basis payment on the delivery terms and this may cause a cancellation of order from the customer since the anticipated items would not be delivered on time. Several factors can lead to the failure of a company and determinants of financial distress are important to the company, bankers, investors, the asset manager and rating agencies. Early signs of financial distress can help the manager to take preventive actions to save the company from falling prey to distress. Any economic agent that has any interest with the company namely shareholders, managers, employees, bankers and clients will be affected with the company's failure. Therefore, the main objective of this study is to determine financial distress among the companies Practice Note 17 (PN17) listed in Bursa Malaysia by using the Altman Z-Score Model as a proxy to financial distress. Panel data from 18 companies listed in PN17, Bursa Malaysia for a period of eight (8) years, from 2009 to 2016 were analysed using Fixed Effects Model. This research used the Financial Statement from specific variables that are not used in Altman Z-Score model as potential determinants financial distress. The findings indicate that leverage and profitability are significant determinants of financial distress.
\end{abstract}

\section{Introduction}

The financial position of each company is very important to generate the decision by the stakeholders in selling or buying shares. The performance of the company is also influenced by the global economic position that endanger them into failure; either bankruptcy or nearing bankruptcy. Any economic agent that has any interest with the company; namely shareholders, managers, employees, bankers and clients will be affected by the company's failure. In Malaysia, the depreciation on the Ringgit considerably affects the business involved in export and import such that companies face a collapse 
in their business. The star online Hwa (2010); Kok, (2010) local newspaper mentions that some of the investors are not aware of the PN17 companies' status and seldom keep track of the financial performance of the company they invested in. It further mentions that to invest, a rationale investor will look for companies with good business fundamentals.

The normal sign of a company in distress is usually significant with decline in their profitability and generally give an impact on the cash flow of the company. This will then drain them of their liquidity and will affect the efficiency of the company operation on a timely basis, debt covenants issue, limited access on the traditional debt and equity capital sources and over leverage. This position will cause the key stakeholders, including vendors, customers, and employees to reassess their relationship with the company.

Determinants of financial distress and prediction failure of the companies is considered a very popular topic and various studies have been conducted on this topic. Most of the studies focus on the Current ratio, Acid test ratio, Cash per share, Cash ratio, Debt to equity, Inventory turnover, Debit turnover per day, Credit turnover per day, Current asset turnover, Fixed assets turnover, Total assets turnover, Net profit margin, Shareholders fund per share, Revenue per share, Interest cover, Price per book value, Earnings growth, Return on shareholders, Turnover growth, Price performance Debt Ratio, Interest Coverage and total asset turnover as a measurement of their studies.

Numerous studies have been conducted on financial distress using the Altman Z-Score model, logic model and probit model. Past studies related to Altman Z-Score as Mantziaris-Zafiiris \& MantziarisZafeiris (2015), Timmermans \& Finance (2014), Thai, Goh, HengTeh, Wong, \& San Ong (2014), Mamo (2011) and Mohammed (2012) is mostly tested the applicability Altman Z-Score with the same ratio use in the model to predict bankruptcy and financial distress. However, most of the researcher in Malaysia is more preferred use logic model in their studies. As the recent studies conducted by Nur Hafizah (2015), Idris (2008), Liloshna et al (2017) is use logic model in determined the financial distress. Other than that, the most studies conducted is only focus on certain industries.

Considering financial position of each company is very important to the company, therefore this study will identify the main determinants of financial distress to the company. In addition to the limited recent studies have been conducted in Malaysia using the Altman Z-Score Model, this study however sought to match the same ratios used by the researchers with Altman Z-Score model Multiple Discriminant Analysis (MDA) linear regression as a proxy to financial distress as opposed to bankruptcy itself with different ratio in intention to fill the gap to determine financial distress in various sector in Malaysia.

The paper is organized as follows. Section two (2) briefly summarizes the relevant theory and literature on determinants of factors on the failure of the company. Section three (3) will discusses the theoretical framework, regression model, estimation technique, and hypothesis and data collection method. Section four (4) will presents the empirical results of the analysis, and Section five (5) concludes the paper. 
INTERNATIONAL JOURNAL OF ACADEMIC RESEARCH IN BUSINESS AND SOCIAL SCIENCES

Vol. 8, No. 11, Nov, 2018, E-ISSN: 2222-6990 @ 2018 HRMARS

multi-leveled equations, graphics, and tables are not prescribed, although the various table text styles are provided. The formatter will need to create these components, incorporating the applicable criteria that follow.

\section{Literature Review}

According to Van der Colff (2012), since the mid-sixties numerous studies have been conducted in the field of company failure prediction. Various models evolved, and each is confident in predicting company failure with reasonable accuracy. These models, representing financial variables based on audited financial results, typically utilise data mining technique. This includes the multivariate discriminant analysis, logistical regression analysis, probit analysis, generic algorithms, neural networks, decision trees and other statistical and calculation methods. The existing models have covered on the bankruptcy and some models on the financial distress.

According to Timmermans \& Finance (2014), ability to predict bankruptcy is very valuable to the company with ability to have clear date which company goes to bankruptcy, however it is hard to define the good criterion of company have a financial distress. Adnan Aziz \& Dar (2006) classified the techniques into three board categories, namely classical statistical models, artificially intelligent expert system (AIES) models and lastly theoretical models. Classical models depend on the companies' account report to find symptoms of company failure. AlES model main features is to focus on symptoms of failure usually drawn from company accounts, result of technological advancement and informational development and depend heavily on computer technology. On the other hand, theoretical model main features is focusing on qualitative causes of failure, mainly drawn from information that could satisfy the theoretical, argument of firm failure proposed by the theory, multivariate in nature and usually employ a statistical technique to provide a quantitative support of the theoretical argument.

According to Khong, Low, Tee \& Wan Lim (2015) and Mohammed (2012), most of the researchers in the past have done studies on the prediction of failure in companies in various sectors. Some studies in Malaysia focused on the PN17 companies listed in Bursa Malaysia and others in general selection (Thai et al., 2014).

One factor that contributes to financial distress of a company is profitability. Profitability refers to the capability of a firm to generate profits in their business. According to Chancharat, (2008) the more a firm generates profit, the greater the funds increase in liquidity. Negative earnings influences firm to file in financial distress. Profitability can be measured in three ways; earnings before interest (EBIT) margin, return on equity (ROE) and return on assets (ROA). The most common tool to measure firm's profitability is ROA. To measure profitability, Altman Z-Score model rely on Earnings Before Interest and Tax to Total Assets (EBITTA). Nur Hafizah (2015), Idris (2008), Liloshna et al (2017) also proves that profitability significantly affect financial distress in a positive way.

Liquidity ratio is used to measure the short term solvency. In other words, it can also measure the firm's ability to meet its current obligations as they become due. A higher level of liquidity decreases the likelihood of financial failure (Khunthong, 1997). Nur Hafizah, (2015) also confirmed that the more liquid of the company, the probability of distress is decreased by using the ratio of Working Capital to Total Assets (WCTA). This is consistent with Beaver (1966), Altman (1968) and Ohlson (1980). 
According to Chancharat (2008) analysis of leverage ratio is concerned on the capital structure of the firm. This ratio shows the shareholder benefit from the origin fund provided by the external sources. Khunthong (1997) defined the leverage ratio to measure the ability of the firms to pay long terms liabilities. In addition, it can measure the long term solvency of firms. Timmermans \& Finance (2014) found that leverage is still important factor in predicting bankruptcy with high leverage were more likely to go bankrupt. Altman Z-Score in his model use leverage ratio which is Retained Earnings to Total Assets (RETA) as the predictor to the financial distress linear combination. Nur Hafizah (2015) in her study found that high leverage of a company can lead to bankruptcy. The ratios used were Total Debt to Total Asset (TDTA) and Current Liabilities to Working Capital (CLWC). Meanwhile Liloshna et al (2017) in their study also found that leverage ratio based on Total Debt per Total Equity (TDTE) is significant in predicting financial distress.

The study conducted by Nur Hafizah (2015) found that there is no significant relationship between the sales growth with the company financial distress. However, the study conducted by Nyamboga et al (2014) found growth to be the most significant determinant of corporate financial distress. Timmermans \& Finance (2014) in his study found the growth ordered high in relative contribution and important in predicting corporate bankruptcy in recalibrated model. According to Abdullah et Al (2009) it is expected the greater the growth the healthier the company. In the study conducted by Platt \& Platt (2008) found that the sales growth is significant to the financial distress in Asia and Europe country. He concludes that the faster turnover of the sales is, the less chance of the company facing financial distress.

Comparing classical model, Ohlson (1980) in his model only use size to predict the financial distress and bankruptcy to the corporate. He found that size is a highly significant predictor for the likelihood of going bankrupt. A lot of researchers use the size of company to predict the significance of the financial distress and bankruptcy. In the model, smaller company is more likely to go bankrupt with the expected of the larger size of the company the lower probability of bankruptcy. The researcher further extended by Lennox (1999) to examine the cause of the UK listed companies filing to bankruptcy and found that small company is more likely to become fail compared to the large company. In 2003 research done by Nikitin (2003) in his study of Plant failure and survival in the Indonesian financial crisis found that size is the major determinant on the Indonesia business survival. This is then supported by the researched done by Dyrberg (2004) which came out with the hypothesis that small firms are in higher probability to face financial distress as they are not resistant to the shocks they might encounter. However, he added that large firms that file financial distress because of inflexible organisations, manager and employees monitoring problem and lack of providing efficient communication. Abdullah et al (2014) in his study found that age is a significant difference with the healthy and distress company. Yusof \& Azhar (2008) in his study of Financial Distress Risk and Stock Returns: Evidence of the Malaysian Stock Market found that size has a significant in the financial risk. This result is significant with the study done by Matyatim (2006). However, Timmermans \& Finance (2014) in his study and the recalibrated model found that size became a less important factor in predicting bankruptcy. 
INTERNATIONAL JOURNAL OF ACADEMIC RESEARCH IN BUSINESS AND SOCIAL SCIENCES

Vol. 8, No. 11, Nov, 2018, E-ISSN: 2222-6990 @ 2018 HRMARS

\section{Methodology}

\section{Sampling Design}

This is a hypothesis testing study that determines the relationship between financial distress companies' specific variables with the Altman Z-Score financial distress model linear combination. The unit of analysis is all PN17 companies listed in Bursa Malaysia in year 2017. There are 18 companies that fall under Practice Note 17 (PN17). Seven (7) from 18 companies listed in Bursa Malaysia are from Manufacturing sectors followed by three (3) from food and beverage, three (3) from oil and gas, and one each from publication, production, insurance, construction and service sectors. The final sample consists of 144 PN17 companies from 2009 to 2016.

\section{Empirical Model}

Table 1 : Variables, Proxies and Methods of Computation

\begin{tabular}{|c|c|c|c|}
\hline Variable & \multicolumn{2}{|c|}{ Proxy and Method of Computation } & Reference \\
\hline $\begin{array}{l}\text { Altman Z-Score } \\
\text { Model (BETA) }\end{array}$ & \multicolumn{2}{|c|}{$\begin{array}{l}\text { Proxy: Beta of PN17 companies } \\
\text { Method of computation: } \\
\text { Z-score }=1.2 \mathrm{~T} 1+1.4 \mathrm{~T} 2+3.3 \mathrm{~T} 3+0.6 \mathrm{~T} 4+1.0 \mathrm{~T} 5 \\
\mathrm{~T} 1=\text { Working Capital } / \text { Total Assets } \\
\mathrm{T} 2 \text { = Retained earnings /Total Assets } \\
\text { T3 = Earnings before Interest and Tax / Total Assets } \\
\text { T4 = Market Value of Equity / Total Liabilities } \\
\text { T5 = Sales/Total Assets }\end{array}$} & $\begin{array}{l}\text { (Mamo, 2011) } \\
\text { (Timmermans \& Finance, 2014) }\end{array}$ \\
\hline Profitability $(P R F)$ & \multicolumn{2}{|c|}{$\begin{array}{l}\text { Proxy: Return on Assets } \\
\text { Method of computation: }\end{array}$} & $\begin{array}{l}\text { (Nur Hafizah, 2015), (Idris, } \\
\text { 2008), }\end{array}$ \\
\hline Leverage (LEV) & $\begin{array}{l}\text { Proxy: Debt Ra } \\
\text { Method of con } \\
\text { LEV = }\end{array}$ & $\begin{array}{l}\text { tion: } \\
\text { Total Liabilities } \\
\text { Total Asset }\end{array}$ & (Nur Hafizah, 2015), (Idris, 2008) \\
\hline Liquidity (LIQ) & \multicolumn{2}{|c|}{$\begin{array}{l}\text { Proxy: Quick Ratio } \\
\text { Method of computation: }\end{array}$} & $\begin{array}{ll}\text { (Nur Hafizah, 2015), } & \text { (Idris, } \\
\text { 2008),(Zmijewski, } & \text { 1984), } \\
\text { (Liloshna et al., 2017), } & \end{array}$ \\
\hline $\begin{array}{l}\text { Growth of Sales } \\
(G R W)\end{array}$ & $\begin{array}{l}\text { Proxy: Annual } \\
\text { Method of con } \\
\text { GRW }\end{array}$ & $\begin{array}{l}\text { tage in sales } \\
\text { tion: } \\
\text { Sales Year } 2 \text { - Sales Year } 1 \\
\text { Sales Year } 1\end{array}$ & $\begin{array}{l}\text { (Nur Hafizah, 2015), (Nyamboga } \\
\text { et al., 2014), (Timmermans \& } \\
\text { Finance, 2014) }\end{array}$ \\
\hline $\begin{array}{l}\text { Size of company } \\
(S I Z E)\end{array}$ & Proxy: Compar & otal Assets & $\begin{array}{l}\text { (Ohlson, 1980), (Lennox, 1999), } \\
\text { (Nikitin, 2003), (Dyrberg, 2004), }\end{array}$ \\
\hline
\end{tabular}

Panel data which is also known as longitudinal data is a combination of cross section and time series data. The data set consists of several units $i$ that is observed across time $t$. The units, $i$, could be individuals, companies, states or countries. This is the advantage of the panel data (Baltagi, 2008). In 
INTERNATIONAL JOURNAL OF ACADEMIC RESEARCH IN BUSINESS AND SOCIAL SCIENCES Vol. 8, No. 11, Nov, 2018, E-ISSN: 2222-6990 @ 2018 HRMARS

the case of this study, the units are PN17 companies listed in Bursa Malaysia that are observed from 2009 to 2016. Panel data analysis started with Pooled Ordinary Least Square model (POLS) and Fixed Effect model. Then, Likelihood Ratio Test is conducted to determine which model fits the sample data better between the two. If Fixed Effect model is selected, the Random Effect model will be estimated. Hausman Test is then conducted to determine which model fits the sample better between Fixed Effect model and Random Effect model.

The relationship between Altman Z-Score Model of financial distress and its determinants is tested using the proposed regression model:

Where,

$$
Y i, t=B 0+B 1 L E V i, t+B 2 L I Q i, t+B 3 P R F i, t+B 4 G R W i, t+B S I Z E i, t+E i, t
$$

$Y i, t=$ Altman Z-Score Financial Distress of company $i$ at year $t$

$L E V i, t=$ Leverage (Debt Ratio) of company $i$ at year $t$

$L I Q i, t=$ Liquidity (Quick Ratio) of company $i$ at year $t$

$P R F i, t=$ Profitability (ROA) of company $i$ at year $t$

$G R W i, t=$ Growth (Sales growth) of company $i$ at year $t$

$S I Z E i, t=$ Size (Logarithm Total Assets) of company $i$ at year $t$

\section{Results and Discussion}

Table 1 : Descriptive Statistic for all PN17 Companies

\begin{tabular}{lllllll}
\hline & Y & LEV & LIQ & PRF & \multicolumn{1}{l}{ GRW } & \multicolumn{1}{l}{ SIZE } \\
\hline Mean & -2760.847 & 263.4755 & 83.17774 & -199.1482 & 8.569589 & 17.84678 \\
Median & -1.085746 & 0.668242 & 0.971221 & -0.065745 & -0.091134 & 18.35319 \\
Maximum & 3109.052 & 12545.80 & 11139.18 & 315.7898 & 1221.894 & 22.87502 \\
Minimum & -232249.4 & 0.021805 & 0.044148 & -28053.32 & -1.000000 & 6.988413 \\
Std. Dev. & 22721.98 & 1458.662 & 928.0982 & 2338.846 & 101.8248 & 2.773517 \\
Skewness & -8.858623 & 7.887773 & 11.86223 & -11.85271 & 11.87201 & -1.445467 \\
Kurtosis & 83.29815 & 65.25492 & 141.8102 & 141.6593 & 141.9655 & 6.006820 \\
Jarque-Bera & 40570.16 & 24747.26 & 118986.7 & 118730.1 & 119251.2 & 104.3908 \\
Probability & 0.000000 & 0.000000 & 0.000000 & 0.000000 & 0.000000 & 0.000000 \\
Sum & -397561.9 & 37940.47 & 11977.60 & -28677.34 & 1234.021 & 2569.936 \\
Sum Sq. Dev. & $7.38 \mathrm{E}+10$ & $3.04 \mathrm{E}+08$ & $1.23 \mathrm{E}+08$ & $7.82 \mathrm{E}+08$ & 1482667. & 1100.013 \\
Observations & 144 & 144 & 144 & 144 & 144 & 144 \\
\hline
\end{tabular}

The mean measures the average value for each variable; LEV, LIQ, PRF, GRW and SIZE in which the mean is $263.4755,83.17774,-199.1482,8.569589$ and 17.84678 . The result for Beta shows the minimum value is -232249.4 while the maximum value is 3109.052 . Skewness and kurtosis values are analysed to observe the shape of the distribution of sampled data. A normal distribution of the Skewness is 0 and Kurtosis is 3. 
INTERNATIONAL JOURNAL OF ACADEMIC RESEARCH IN BUSINESS AND SOCIAL SCIENCES

Vol. 8, No. 11, Nov, 2018, E-ISSN: 2222-6990 @ 2018 HRMARS

Table 2 : Fixed Effects Model

\begin{tabular}{llll}
\hline Variable & Coefficient & t-Statistic & Prob. \\
\hline \hline C & 2345.292 & 1.215276 & 0.2266 \\
LEV & -11.66724 & -75.85051 & 0.0000 \\
LIQ & -0.000386 & -0.003009 & 0.9976 \\
PRF & 3.077984 & 44.93259 & 0.0000 \\
GRW & -0.011818 & -0.010198 & 0.9919 \\
SIZE & -79.51006 & -0.745501 & 0.4574 \\
\hline
\end{tabular}

The $p$-value in the Fixed Effect Model has resulted in Leverage (LEV) and Profitability being less than $a=0.05$, meaning that the null hypothesis was rejected and it can be concluded that the independent variable is significant at $5 \%$ level of significance. Therefore, this study provides evidence that Leverage by using the ratio Total Liabilities to Total Assets (TLTA) ratio and Profitability by using Net Income to Total Asset (NITA) are significant determinants of financial distress among PN17 companies listed in Bursa Malaysia.

Profitability has the largest coefficient with significant $p$-value, thus it is the most significant determinant of financial distress among PN17 companies listed in Bursa Malaysia. Profitability has a positive coefficient suggesting that holding other variables constant a $1 \%$ change in the profitability of the company has a significant impact of $3.077984 \%$ on financial distress increment. This is significant with the original study done by Beaver (1966), Ohlson (1980) and Zmijewski (1984) that uses Net Income to Total Asset as represented in the Profitability are important factors of financial distress. This result is further supported by the recent study done by Idris (2008), Mamo (2011), Nur Hafizah (2015) and Liloshna et al. (2017). According to Idris (2008) he concluded that companies that have better profitability are often seen as being better managed. The profits generated by the companies will indicate the company's performance.

The leverage (LEV) even has the negative coefficient result -11.66724 however the $p$-value is significant at $5 \%$ level. The result shows that Leverage (LEV) is still an important factor to determine financial distress by measuring the debt ratio, Total Liabilities to Total Assets (TLTA). This is significant with the study done by Ohlson (1980), Beaver (1966) and Zmijewski (1984). This result is significant in the study done by Abdullah et al. (2014) using logistic regression that found TLTA is the only significant variable to predict financial distress to SME's companies in Malaysia. This ratio measures the assets of companies' finance by debt. The result is significant with the other studies done by Liloshna et al. (2017) and Nur Hafizah (2015) that concluded the higher leverage will lead to the bankruptcy.

The liquidity however shows that there is negative coefficient and not an important factor to predict financial distress and contradicts with the original Altman Z-Score model (Altman, 1968), (Idris, 2008) and (Thai et al., 2014). Even though the study conducted by Idris (2008) found that liquidity is significant to predict financial distress the financial ratio significant are only Working Capital to Total Asset (WCTA) as used in Altman Z-Score model, Cash to Total Asset (CashTA) and Current Asset to Total Assets (CATA). He then found that liabilities financial ratio which are Working Capital to Sales (WCSales) and Current Asset to Current Liabilities (CACL) is not significant to predict financial distress. 
Even the characteristic of current ratio is to measure the ability of the company to pay short term obligation like debt and payables by checking on shortage of current assets that will represent the companies either have or do not have enough of liquid assets to cover their short-term obligation where current liabilities. This research further contradicts the study conducted by Khaliq et al. (2014) where it was found that the CACL has a strong relationship with Altman Z-Score model. It is supported by other results of the study done by Sulaiman, Jili, \& Sanda (2001) that also contradicts with this study where is CACL was found to have a positive relationship with financial distress.

The Sales growth as Nur Hafizah (2015) study is significant that there is negative coefficient to predict financial distress. The Size of company is still not an important variable as a financial distress factor of the company. This is however contradicting with the Ohlson (1980).

The F-statistic generated for PN17 companies is 1938.578 with $p$-value of 0.000000 . The $p$-value is less than $a=0.01$ meaning that the Fixed Effects model is significant at $1 \%$ and fits the sample data well. The adjusted R-squared value is 0.996657 , which shows that the selected independent variables can explain $99.67 \%$ of the variation in financial distress PN17 companies. The value is more than $50 \%$ implies that critical variables that may affect the financial distress is included in the models.

\section{Conclusion}

Based on the result obtained, there are two independent variables found to have significant relationship with financial distress proxy, whereby the other three were found to have insignificant relationship. Those variables that have impact on proxy of Distress Company were profitability and leverage. On the other hand, liquidity, growth and size did not have any impact on the financial distress's proxy in this study.

Leverage, have negative relationship with the proxy of financial distress. When the liabilities increase, the major company's assets are expected is finance by debt. On the other hand, the higher the level of debt of the firm, higher tendencies for the firm to be exposed with risks of bankruptcy. In the other words, high leverage in the firm affects the firm's debt service coverage and results in financial distress. However, if the sales increase, high leverage is good, and it is bad if the sales are falling. Generally, when the profitability increases, the firms are expected to have sufficient capital to sustain its business which constitutes to negative relationship. However, this study depicted a positive relationship between the profitability and financial distress because the sample used in this study is the PN17 companies. In other words, companies that are categorised under PN17 are mostly companies that having a financial distress issue. The Altman Z-Score model is concluding that the higher score is meaning company has a higher chance to avoid bankruptcy. The finding was in line with the earlier hypothesis.

Therefore, based on the result obtained, profitability was the major factor that influenced the Altman Z score in PN17 companies. The profitability was the highest coefficient among other variables. On the other hand, leverage being the least factor that could impact the Altman Z score ratio in this study which shows lower coefficient. 
INTERNATIONAL JOURNAL OF ACADEMIC RESEARCH IN BUSINESS AND SOCIAL SCIENCES

Vol. 8, No. 11, Nov, 2018, E-ISSN: 2222-6990 (C) 2018 HRMARS

\section{References}

Abdullah, N. A. H., Rus, R. M., Halim, A., \& Ahmad, H. (2009). Factors contributing to financially distressed companies in Malaysia.

Abdullah, N. A. H., Zainudin, N., Ahmad, A. H., \& Rus, R. M. (2014). Predictors of financially distressed small and medium-sized enterprises: a case of Malaysia. International Proceedings of Economics Development and Research, 76, 108.

Adnan Aziz, M., \& Dar, H. A. (2006). Predicting corporate bankruptcy: where we stand? Corporate Governance: The international journal of business in society, 6(1), 18-33.

Altman, E. I. (1968). Financial ratios, discriminant analysis and the prediction of corporate bankruptcy. The journal of finance, 23(4), 589-609.

Asteriou, D., \& Hall, S. G. (2015). Applied econometrics: Palgrave Macmillan.

Baltagi, B. (2008). Econometric analysis of panel data: John Wiley \& Sons.

Beaver, W. H. (1966). Financial ratios as predictors of failure. Journal of accounting research, 71-111.

Chancharat, N. (2008). An empirical analysis of financially distressed Australian companies: the application of survival analysis.

Dyrberg, A. (2004). Firms in financial distress: An exploratory analysis.

Grewal, R., Cote, J. A., \& Baumgartner, H. (2004). Multicollinearity and measurement error in structural equation models: Implications for theory testing. Marketing Science, 23(4), 519-529.

Hwa, O. K. (2010). What is a PN17 company? Do you sell or buy its shares.

Read more at http://www.thestar.com.my/business/business-news/2010/07/14/what-is-a-pn17company-do-you-sell-or-buy-its-shares/\#YrBkqvbl5Qt5YYG9.99. The Star.

Idris, N. F. (2008). Financial ratios as the predictor of corporate distress in Malaysia. University of Malaya.

Khaliq, A., Altarturi, B. H. M., Thaker, H. M. T., Harun, M. Y., \& Nahar, N. (2014). Identifying Financial Distress Firms: A Case Study of Malaysia's Government Linked Companies (GLC). International Journal, 3(3).

Khong, L. Y., Low, C. S., Tee, L. P., \& wan Lim, L. (2015). Corporate Failure Prediction in Malaysia. Journal of Research in Business, Economics and Management, 4(2), 343-375.

Khunthong, J. (1997). Red flags on financial failure: the case of Thai corporations. 
INTERNATIONAL JOURNAL OF ACADEMIC RESEARCH IN BUSINESS AND SOCIAL SCIENCES

Vol. 8, No. 11, Nov, 2018, E-ISSN: 2222-6990 (C) 2018 HRMARS

Kok, H. (2010). What is a PN17 company? Do you sell or buy its shares. The star online, July 14. Retrieved July 19, 2010.

Liloshna, L., Sharmila, L., Felix, G., Nair, M., Nair, B., \& Tushaline, S. (2017). A Study on the Predictions of Financial Distress in Malaysia. UTAR.

Low, S.-W., Nor, F. M., \& Yatim, P. (2001). Predicting corporate financial distress using the logit model: The case of Malaysia. Asian Academy of Management Journal, 6(1), 49-61.

Mamo, A. Q. (2011). Applicability of Altman (1968) model in predicting financial distress of commercial banks in Kenya. PhD diss.

Mantziaris-Zafiiris \& Mantziaris-Zafeiris, S. (2015). Bankruptcy prediction models: an empirical analysis of Altman's Z-Score model in forty greek companies in the period of economic recession.

Matyatim, R. (2006). The Classification Model for Corporate Failures in Malaysia.

Mohammed, A. A. E. (2012). Financial situation of PN17 companies listed in the Malaysian stock exchange. Universiti Tun Hussein Onn Malaysia.

Nikitin, G. (2003). Plant failure and survival in the Indonesian financial crisis. Job Market Paper., Boston University November.

Nur Hafizah, R. (2015). Determinants of financial distress among manufacturing companies in Malaysia. Universiti Utara Malaysia.

Nyamboga, T., Omwario, B., Muriuki, A., \& Gongera, G. (2014). Determinants of Corporate Financial Distress: Case of Non-Financial Firms Listed in the Nairobi Securities Exchange. Research Journal of Finance and Accounting, 5(12), 193-207.

Ohlson, J. A. (1980). Financial ratios and the probabilistic prediction of bankruptcy. Journal of accounting research, 109-131.

Platt, H. D., \& Platt, M. B. (2008). Financial distress comparison across three global regions. Journal of Risk and Financial Management, 1(1), 129-162.

Sulaiman, M., Jili, A., \& Sanda, A. U. (2001). Predicting corporate failure in Malaysia: An application of the Logit Model to financial ratio analysis. Asian Academy of Management Journal, 6(1), 99-118.

Thai, S. B., Goh, H. H., HengTeh, B., Wong, J., \& San Ong, T. (2014). A Revisited of Altman Z-Score Model for Companies Listed in Bursa Malaysia. International Journal of Business and Social Science, 5(12). 
INTERNATIONAL JOURNAL OF ACADEMIC RESEARCH IN BUSINESS AND SOCIAL SCIENCES

Vol. 8, No. 11, Nov, 2018, E-ISSN: 2222-6990 (C) 2018 HRMARS

Timmermans, M., \& Finance, M. (2014). US Corporate Bankruptcy Predicting Models.

Van der Colff, F. (2012). Company financial failure and distress: a perspective.

Yi, Y., \& Wang, X. (2011). Comparison of Wald, score, and likelihood ratio tests for response adaptive designs. Journal of Statistical Theory and Applications, 10(4), 553-569.

Yusof, M., \& Azhar, M. (2008). Financial distress risk and stock returns: evidence of the Malaysian stock market. University of Malaya. 